\title{
Adam and Eve's Wifiq: From Mathematics to Transformation Practice
}

\author{
Rusli Rusli ${ }^{*}$, Abdussakir ${ }^{2}$, Asni Furaida ${ }^{3}$ \\ ${ }^{1}$ Physics Department, UIN Maulana Malik Ibrahim Malang, Indonesia \\ ${ }^{2}$ Mathematics Department, UIN Maulana Malik Malang, Indonesia \\ ${ }^{3}$ English Literature Department, UIN Maulana Malik Ibrahim Malang, Indonesia \\ *Corresponding Author. Email: rusli@fis.uin-malang.ac.id
}

\begin{abstract}
Indonesian society still believes in and uses wifiq. One of which often used is Adam and Eve's wifiq. It is the basic of making other talismans. This wifiq is used for compassion, safety, treatment and other efficacy. This wifiq is called Adam and Eve's because mathematically the number of Adam's name equal to 45 and Eve's is equal to 15 which is interpreted that Eve is made of Adam's ribs. Wifiq can also be taken from the beginning of the Surah in Quran that is a combination of kaf ha ya ain shad and ha' mim ain sin qaf with mathematical calculation, then it gets a talisman. If the Adam and Eve's wifiq is considered as a matrix then a mathematical operation can be done by calculating the characteristic roots or addition of eigen value with the results of 15. This number corresponds to the sum of the columns, rows or diagonals of this talisman. The same characteristic root value will provide the energy of harmony to the purpose of its manufacture. The transformation of Adam and Eve's wifiq is by contouring the wifiq which can be used as accessories in t-shirts and cups/mugs so that they can be used with confidence.
\end{abstract}

Keywords: Adam, Eve, Magic Square, Mathematic, Wifiq.

\section{INTRODUCTION}

Indonesian society still believes and uses wifiq [1]. There are those who believe but are reluctant to use it for various reasons, such as prestige, ancient and so on. Therefore, the authors carry out a transformation of the existing wifiq, which in this study are Adam and Eve's wifiq. The goal in the wifiq transformation is so that wifiq can be used and adapted to today's era [2], although it changes the appearance but does not change the essence and existence of wifiq.

The Republic of Indonesian owes much to this mystical tradition. In the struggle against the Dutch colonialism, wifiq became one of the most powerful weapons in the battle [3]. Realizing that wifiq was used as one of the weapons of the struggle against the Dutch colonialism, the wifiq law was enacted in wetboek van Strafrench's. It can be read in Article 547 of the Criminal Code, "a witness who, when asked to testify under oath according to the provisions of the law, in a court hearing using wifiq or magic objects, is threatened with a maximum imprisonment of ten days or a maximum fine of seven hundred and fifty rupiahs".

One of the most widely used wifiq is the Adam and Eve's wifiq. Adam and Eve's wifiq is a talisman that has a shape of $3 \times 3$ magic squares, each square filled with number 1 to 9 . Magic square is a number arrangement in squares that has rectangle shape with the nature of numbers according to each row, column, or diagonals which is similar [4]. Magic squares of $\mathrm{n} \mathrm{x}$ $\mathrm{n}$ size, as many as $\mathrm{n} \times \mathrm{n}$ numbers are arranged in square boxes provided that there are no numbers written repeatedly and the numbers are according to each row, column and diagonal are the same. Adam and Eve's wifiq is usually written in the form of Arabic letters and figures, as shown below. 


\begin{tabular}{|c|c|c||c|c|c|}
\hline$\varepsilon$ & $q$ & $r$ & $د$ & $b$ & $\varphi$ \\
\hline$r$ & 0 & $V$ & $?$ & 0 & $j$ \\
\hline$\Lambda$ & 1 & $r$ & $\tau$ & $i$ & 9 \\
\hline \multicolumn{3}{|c|}{ A }
\end{tabular}

Figure 1. A. Adam and Eve's wifiq in the form of numbers and B. in letters

The $3 \times 3$ magic square of Adam and Eve's wifiq is first told in Ancient China. Kungfutse tells at that time there was a just and wise emperor who ruled between 2025 and 2198 BC. The emperor is Emperor $\mathrm{Yu}$, known for his wisdom and high precision. He once built a dam in the Yellow river to prevent flood. When he was sitting while pondering on the edge of the river suddenly a turtle God named Hi emerged. There is a picture on the back of the turtle in the form of numerical signs which after being transcribed in modern figures look similar to Adam and Eve's wifiq [5].

In Islamic civilization in the Middle East, the earliest wifiq writing was during the Abbasiyah dynasty and written by Tsabbit ibn Qurrah, then continued in Rasa'il Ikhwan as Shafa. The more comprehensive wifiq was written by Ahmad Ibn Muhammad Al-Ghazali (Imam Ghazali's younger brother) in Al-Awfaq (plural form of wafaq) [6]. Then the book of Syamsul Ma'arif Kubro was published written by Ahmad Ibn Ali Al-Buni (d. 1225), and is still well-known among Islamic boarding schools until now.

Adam and Eve's wifiq has four character forms i.e. earth, water, wind and fire. There are those who divide it based on four angels, namely Izrail, Mikail, Israfil and Jibril. There is also a division based on planets and stars in the sky. Each of these divisions has its own character and efficacy. It is shown in the table 1.

Table 1. Adam and Eve's wifiq divisions table and its characteristics [7]

\begin{tabular}{|c|c|c|c|}
\hline Azrael & Michael & Israfel & Gabriel \\
\hline $\begin{array}{lll}4 & 9 & 2\end{array}$ & 672 & 276 & 816 \\
\hline $\begin{array}{lll}3 & 5 & 7\end{array}$ & 159 & $\begin{array}{lll}9 & 5 & 1\end{array}$ & $\begin{array}{lll}3 & 5 & 7\end{array}$ \\
\hline 816 & $\begin{array}{lll}8 & 3 & 4\end{array}$ & 438 & $\begin{array}{lll}4 & 9 & 2\end{array}$ \\
\hline $\begin{array}{l}\text { Earthly, Northern, } \\
\text { Cold and Dry }\end{array}$ & $\begin{array}{l}\text { Watery,Southern, } \\
\text { Cold and Moist }\end{array}$ & $\begin{array}{l}\text { Aerial, Western, } \\
\text { Hot and Moist }\end{array}$ & $\begin{array}{l}\text { Fiery, Eastern, } \\
\text { Hot and Dry }\end{array}$ \\
\hline $\begin{array}{l}\text { Separation, } \\
\text { Betrayal, and } \\
\text { Imprisonment }\end{array}$ & $\begin{array}{l}\text { Bringing of } \\
\text { Prosperity }\end{array}$ & $\begin{array}{l}\text { Arousing of } \\
\text { Passion and } \\
\text { Attraction }\end{array}$ & $\begin{array}{l}\text { Being well } \\
\text { received and } \\
\text { respected }\end{array}$ \\
\hline Taurus Female & Cancer Female & Gemini Male & Aries Male \\
\hline Virgo Female & Scorpio Female & Libra Male & Leo Male \\
\hline Capricorn Female & Pisces Female & Aquarius Male & $\begin{array}{l}\text { Sagittarius } \\
\text { Male }\end{array}$ \\
\hline
\end{tabular}

According to Ali Abu Hayullah Marzuqi, letters and numbers have different properties following the character of the four elements al hayula al ula (first material), they are al nariyah (fire), al maiyah (water), al hawaiyah (air) and al turabiyah (earth). It is because the movement of the universe emerged to the nature of heat, cold, dry and wet. In the philosophy of emanation in Islam, the first material is the beginning of the universe formation. Therefore, according to Shaikh Jalaludin Abd Al-Rahman Al-Suyuti the nature of the four elements is also found in the human body. When one's body is sick, then there is imbalance of the four elements within the body.
In this paper, the authors will examine Adam and Eve's wifiq from a mathematical approach. The authors will find out whether wifiq is considered a matrix of $3 \times 3$. If so, mathematic operational can be applied on it; for example, seeking the sum of characteristic values or eigen values of a matrix. It also can be added, subtracted and did other operational. The operational results are interpreted and deciphered in the realm of Islamic life and tradition. Then, the transformation is carried out by contouring all elements, namely fire, water, air and earth to form a new look so that it can be used in accessories such as t-shirts and cups/ mugs. 


\section{RESEARCH METHOD}

The first and very crucial method and technique in this research is to convert the abjadiyah letters rules into numbers. According to Ulama, the arabiyah letters are generally divided into two rules. First, Alfabetiyah rule (hijaiyah rules). That letters are composed of $\{$ l ت ث ج ح د ذ ر ز س ش ص ض طظع غ ف ق أك ل من و ه لاء ي) as they are commonly seen and known. The Alfabetiyah rule are made by Nasr bin Ashim and Yahya bin Ya'mur al-'Adawani, during the empire of Abdul Malik bin Marwan. The foundation or basis creation of these rules is the similarity between letters in terms of syllables (forms), rosm (writing) and the number of points received. Second, the Abjadiyah rule

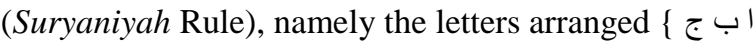

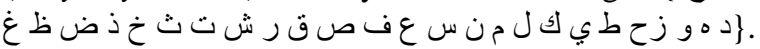
This rule existed before Islam brought by the Prophet Muhammad came and it was even alleged that this rule first appeared when Allah taught the Prophet Adam about names of all things [8]. So, the study is using the rule of Abjadiyah to analyze the Adam and Eve's wifiq above. If the rule is numerated, it will likely be as seen in figure 2.

\begin{tabular}{|c|c|c|c|c|c|c|c|c|c|c|c|c|c|}
\hline ن & $\hat{~}$ & J & ك & ي & ط & $\tau$ & j & و & هـ & د د & ج & ب & 1 \\
\hline 50 & 40 & 30 & 20 & 10 & 9 & 8 & 7 & 6 & 5 & 4 & 3 & 2 & 1 \\
\hline$\dot{\varepsilon}$ & ظ & ض & ذذ & $\dot{\tau}$ & ث & ت & ش & J & ق & ص & ف & $\varepsilon$ & س \\
\hline 1000 & 900 & 800 & 700 & 600 & 500 & 400 & 300 & 200 & 100 & 90 & 80 & 70 & 60 \\
\hline
\end{tabular}

Figure 2. Conversion of Abjadiyah from letters to numbers

Example: the sentence of الله اكبر

Allahu akbar consists of 8 letters namely alif $=1$, lam $=30$, lam $=30, h a=5$, alif $=1, k a f=20, b a^{\prime}=2$ and $r a^{\prime}=200$. Those numbers equal to 289

The second method is to look for the characteristic values of a matrix which in this case is Adam and Eve's wifiq. In Mathematics, the characteristic value is formulated with Det $(\lambda I-A)=0$, where $\lambda$ is the eigen value, $\mathrm{I}$ is the matrix identity and $\mathrm{A}$ is matrix $n \times n$ [9]. In this study, the authors used the Matlab software to help the calculation of the sum characteristics value of wifiq above.

The third method is the transformation of Adam and Eve's wifiq by collecting the four elements of the wifiq so that a $6 \times 6$ matrix is formed. Then the data grid is done with the Kringing and moving average methods, after that coloring and the results are in the form of images. The grid is a matrix structure that is used to implicit record, the topological relationships between data points [10]. In this study the authors use the facilities of the Golden Software Surfer to transform wifiq above. The results of the transformation can be used in t-shirt accessories motifs and cups/ mugs.

\section{RESULT AND DISCUSSION}

Wifiq $3 \times 3$ with number formations as above is called Adam and Eve's wafaq. It is because the word Adam (ادم) consists of three letters. When it is converted into numbers; alif $=1, d a l=4$ and $\operatorname{mim}=$ 40. If added together, it equals to 45 . The number 45 is equal to the sum of all the numbers in wifiq above, namely $1+2+3+4+5+6+7+8+9=45$. Meanwhile, the word Eve (حوا) also consists of three letters, which is converted into $h a^{\prime}=8$, wau $=6$ and alif $=1$ that equal to 15 . The number 15 is equal to the sum of each row, each column or diagonally which is 15 . From numbers 45 and 15, it can get a new perspective that $15 \times 3=45$ which can be interpreted as the Eve's creation from one of Adam's ribs.

This Adam and Eve's wifiq is presenting the balance and union of man and woman. Even numbers (feminine) are in every corner of the table, odd numbers (masculine) are within them. The sacred relationship of man and woman seen above is the same as the yin and the yang in the perspective of China. In addition, it is also show the union of the tetrahedron star and earth tetrahedron in the Star of David in Jewish perspective [11]. When it gets deeper, the Adam and Eve's wifiq above represents a child who is in his mother's womb represented by an odd number in an even number. Therefore, Adam and Eve's wifiq is mostly as a means of compassion, because indeed the basic energy pattern characteristics are shown as it is.

Adam and Eve's wifiq can be traced from the combination of the muqatta'ah كهيعص (kaf ha ya 'ain shad) and حم عست (ha' mim' ain sin qaf). If it is converted in the number two of muqatta'ah letters; $k a f$ 
$=20, h a=5, y a=10$, 'ain $=70$ and shad $=90$; the later consists of $h a^{\prime}=8, \operatorname{mim}=40$, 'ain $=70, \sin =60$ and qaf $=100$. If the letters of the two muqatta'ah letters are combined, they will form a series of $20,5,10,70,90,8,40,70,60$, and 100. This series consists of 10 numbers while the $3 \times 3$ magic square consists of only nine squares and there are also two twin numbers 70 , while in the magic square there should not be the same number. The solution is one of number 70 is removed by $100-70=30$. So, in the beginning, number 100 changes to 30 . The new series is $10,20,30,40,5,60,70,8$, and 90 . If the series is only taken the front number then the new series is obtained 1, 2, 3, 4, 5, 6, 7, 8, and 9. These series are nothing but numbers that are in the magic square box $3 \times 3$ Adam and Eve.

If the Adam and Eve's wifiq is modified as shown in the figure 3 below

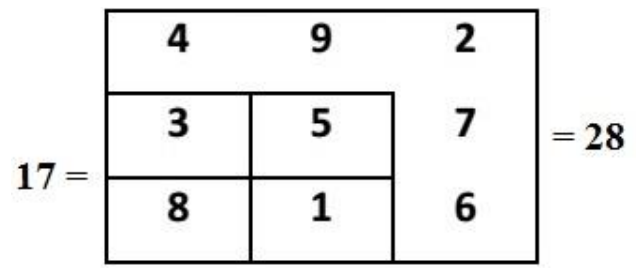

Figure 3. Adam and Eve's Wifiq Modification

then there are two sets of numbers. First 3, 5, 8 and 1 which equal to becomes 17 . Second 4, 9, 2, 7 and 6 that equal to 28 .

Number 17 has an important position in the Islamic mystical tradition. Jabir ibn Hayyan viewed the whole material based on number 17. According to him, the number contains a series of $1,3,5$ and 8 , and these numbers form the basis for all other numbers. If traced further, 17 is the total number of compulsory prayers in a day. Some Sufis consider the word Allahu akbar to consist of 17 letters [12]. From the example above it is known that the word Allahu akbar if it is converted into numbers is 289 , the number 289 is the result of $17 \times 17$ or the square of 17.

Likewise, number 28 plays an important role in Islam, because mystics connect 28 Arabic letters (with which the holy book of the Quran was written) with the points that the moon passes through. A medieval mathematician and historian, al-Biruni (d. 1048) said that this relationship proves the closeness between the cosmos and the words of God. This relationship is in accordance with 28 names of the prophets before Muhammad mentioned in the Quran. Hence, the poets analogized the Prophet Muhammad to the full moon.
In Mathematics, there is the so-called "perfect numbers". Perfect numbers are said if the sum of the factors of a number is equal to the number itself [13]. One perfect number is 28 , because $28=1+2+4+7$ +14 . This perfect number is mentioned in the Dialogue of Plato as a sign of the deity birth [14].

If Adam and Eve's wifiq is considered a 3x3 matrix, then mathematical operations can be carried out by looking for the characteristic root or the sum of the eigen values. With the help of Matlab Program, the sum of the eigen values is 15. It is shown in Figure 4.

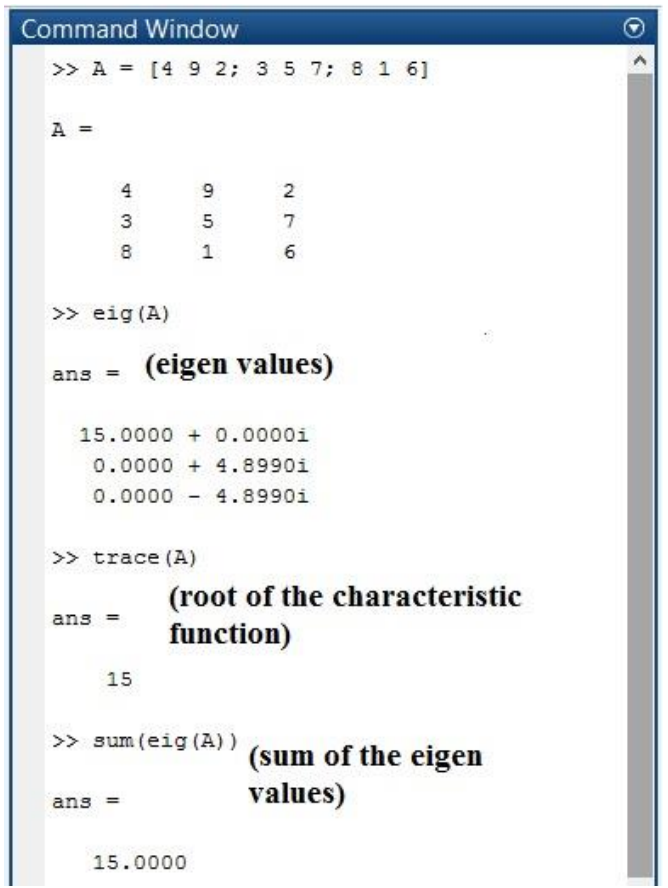

Figure 4. The result of calculating the eigen values for Adam and Eve's wifiq using the Matlab program.

The result of the characteristic root or the sum of the eigen values is 15 . Number 15 is the same as the sum between the rows, columns and diagonal of the magic square of Adam and Eve above. With this equation, there is an energy harmony in the purpose of making the wifiq.

Adam and Eve's wifiq transformation is obtained by collecting elements of those wifiq. This is intended so that the properties in these elements can be united in other forms even though their essence and existence do not change. The grid method only connects from one number to another by interpolating. After that, there is a contour, it is to unite the same and/or almost the same numbers with the aim of giving a color so as to create an image with a certain shape, pattern, and color. 


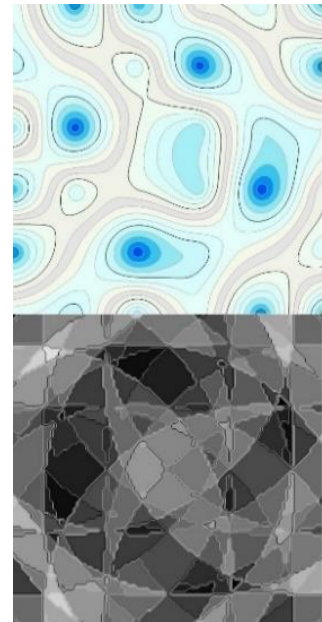

A

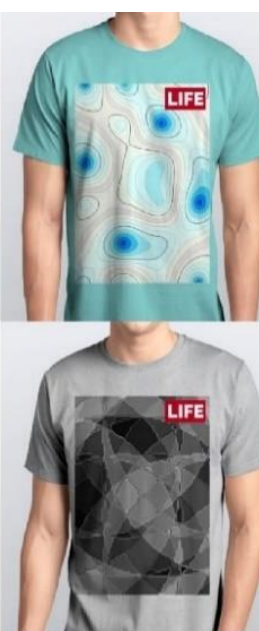

B

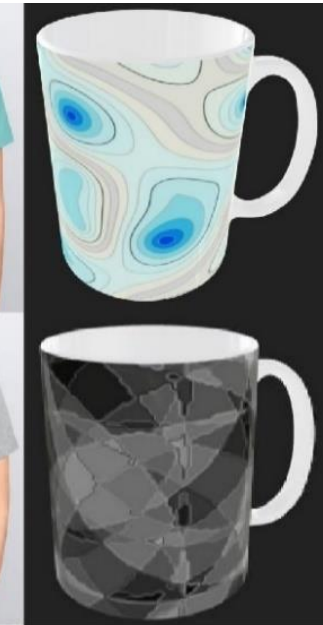

Figure 5. A The result of the transformation of Adam and Eve's wifiq by means of grids and contours. B The use of transformations practice result on t-shirts and mugs.

Figure $5 \mathrm{~A}$ is one of the transformed images of Adam and Eve's wifiq by means of grids, contour, and coloring. There are various grid methods used in this research, namely the Kringing method for the image of figure $5 \mathrm{~A}$ above and the moving average method for the bottom figure. For coloring, people can choose what they want, usually it is adjusted to the color of the container that the wifiq transformation will be placed in. Figure $5 \mathrm{~B}$ is one of the practical uses of the Adam and Eve's wifiq transformation result which is attached to t-shirts and mugs as accessories. So, with the wifiq transformation, it will become something that is contemporary, no longer taboo and those who use it are more confident.

\section{CONCLUSION}

From the long elaboration above, it can be concluded that the Adam and Eve is a wifiq that has existed since the time of Emperor Yu (2025 BC) but for the numbers that fill the magic square, it had existed since the Prophet Adam was sent to earth. It is called Adam and Eve's wifiq because the numbers contained in Adam's name is the same as 45 which corresponds to the sum of all the numbers that are in the wifiq which are numbers 1 to 9 . While the Eve's number contained therein is 15 which corresponds to the addition between lines, column or diagonal. 45 is the result of $15 \times 3$ and can be interpreted that Eve was created from part of Adam's rib.

If the Adam and Eve's wifiq is modified, then we will get the numbers 17 and 28. 17 is denoted from the number of rak'ah from the obligatory prayers and the square of 17 is the numbers contained in the word Allahu Akbar. Meanwhile, 28 is the sum of Abjadiyah letters in the Quran and the numbers of prophets mentioned before Muhammad PBUH. If Adam and
Eve's wifiq is considered to be a matrix after finding the root characteristics or the sum of the eigen values with the help of Matlab program, the number 15 is obtained. 15 is equal to the sum of the rows, columns, and diagonals so the energy of harmony aligns with the aim of making the wifiq. The wifiq transformation is carried out by means of grids and contours and then it is printed on t-shirts and mugs so that they become modern, not taboo and those who wear them become more confident.

\section{REFERENCES}

[1] R. Alviana and Abdussakir. Mathematical Analysis of Numerical Talismans. Cauchy 2(2) (2012) 105-114. DOI: 10.18860/ca.v2i2.2225

[2] M. A. Kholili, N. Rizali, S. Budi. Amulet development: Wifiq "Darkah Ya Ahlal Medina" from Megical Content to Visual Performance. Conference: Proceedings of the 1st Seminar and Workshop on Research Design, for Education, Social Science, Arts, and Humanities, SEWORD FRESSH, 2019, Surakarta, Central Java, Indonesia. DOI:10.4108/eai.27-4-2019.2286875

[3] A. F. Alami. Jimat NU, Ar-Ruzz Media, 2014

[4] J. Sesiano. Magic Squares: Their History and Construction from Ancient Times to AD 1600, Springer, 2019.

[5] J. Moran, The Wonders of Magic Square, Random House Inc, 1982.

[6] M. N. Qasim, Lingua Elements in Wifiq. Jurnal al-Tsaqafa 13(1) (2016) 61-67. DOI: https://doi.org/10.15575/altsaqafa.v13i01.1831 
[7] J. Sesiano. Magic Squares in the Tenth Century: Two Arabic Treatise by Antaki and Busjani, Springer, 2017

[8] N. O. Shadrach, Encyclopedia of Magic Squares: Planetary Angels and Spirit of Ceremonial Magic, Ishtar Publishing, 2009.

[9] A. S. Muhyidin, The Secret of Hijaiyah Letters: Reading Arabic Latters with Theosophy Glasses, Lentera Kreasindo, 2015.

[10] R. Kusumawati, Linear Algebra and Matrix. UIN Malang Press, 2009.
[11] E. Prahasta, Digital Surface Model, INFORMATIKA, 2008.

[12] N. O. Shadrach, Magic Square and Tree of Life: Western Mandalas of Powers, Ishtar Publishing, 2009.

[13] A. Schimmel, The Mysteri of Numbers, Oxford University Press, 1993.

[14] D. S. Naga, Numbers: History and Development, PT. Gramedia, 1980.

[15] K. Menninger, Number Words and Number Symbols: a Cultural History of Numbers, Dover Publication, 2011. 